FERENCZI ATTILA

\title{
HERCULES AZ ALVILÁGBAN
}

\author{
(SENECA HERCULES FURENSÉRŐL)
}

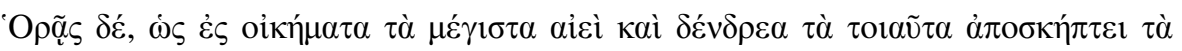

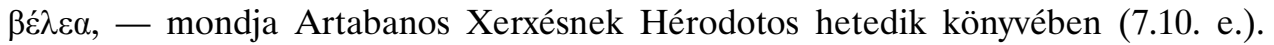

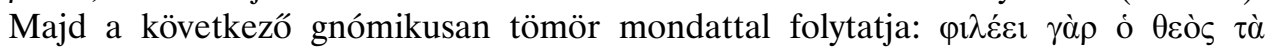

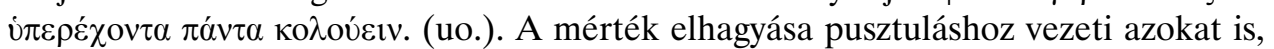
akik az emberi léptéket értékeikkel hagyják maguk mögött. Nem annak az egyszerú természeti törvénynek a megfogalmazása ez, hogy magasról nagyobbat esik az ember, hanem keserú sejtés, miszerint minél feltúnóbb az emberi nagyság, annál bizo-

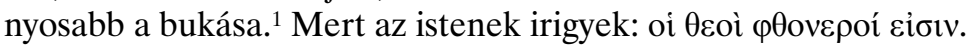

Vélhetőleg még ugyanebben az évtizedben ezt a gondolatot állítja Euripidés „Az őrjöngő Héraklés” c. tragédiája középpontjába. Kétségtelen, hogy a darabban morális értelemben Héraklés nem szolgál rá, hogy tönkretegyék az égiek. Az istenek csapása nem búnei vagy akár csak egyetlen vétsége miatt sújtja a hőst. A pusztító istennő, Lysa maga is vonakodik eleget tenni Héra kérésének, szeretné inkább meggyőzni kísérőjét, Irist arról, hogy Héraklés nem érdemli meg azt, amit az istennôk ellene forralnak, mert mindig az emberek oltalmazója és az égiek hatalmának védelmezóje volt:

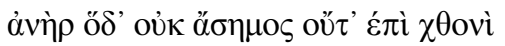

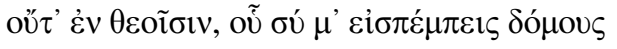

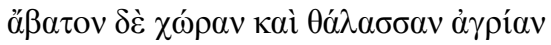

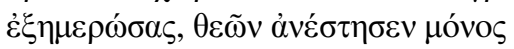

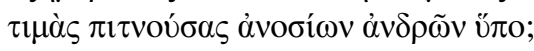

$$
\begin{aligned}
& \text { }
\end{aligned}
$$

Lysa vezetőjének, Irisnek az érveléséből világosan kiderül: egyetlen oka Héraklés bukásának az, hogy túl magasra emelte az emberi nem lehetôségeit, olyan magasságba, amelyet az istenek hatalmukra veszélyesnek ítéltek:

${ }_{1}^{1}$ A motívum további útjához ld. R. G. M. Nisbet—M. Hubbard: A Commentary on Horace: Odes II. Oxford 1978. ad 10. 9. 


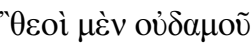

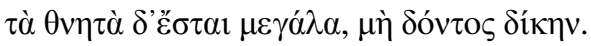

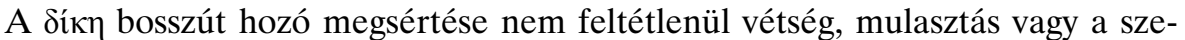
mélyiség valamilyen torzulása, hanem éppúgy magával vonhatja a szokásos mértéket

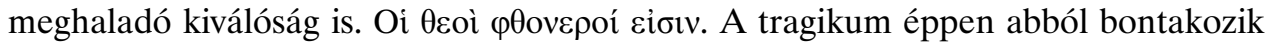
ki, hogy nem a darab elsô részében ábrázolt cselekmény váltja ki a sorsfordulatot: a Héraklés családját fenyegetó veszély és az ôrültség között nincsen oksági összefüggés. ${ }^{2}$ Ennek következtében persze sérül a drámai szerkezet. Már G. Murry törött gerincú múnek nevezte ${ }^{3}$ és azóta is a legtöbb értelmező kiemeli a cselekmény egységének hiányát. ${ }^{4}$

Követi-e a mítosznak ezt az értelmezését Seneca a Hercules furensben? Lehet-e az euripidési gondolatok segítségével értelmezni a római költőutód darabját is? Ez az a kérdés, amely olyan heves vitákat váltott ki a mú elemzóiből, hogy az mára valószínúleg a Seneca-tragédiák legkevésbé egységesen megítélt darabjává vált, és a tudományos disputa egyik résztvevője egyenesen filológusi gigantomachiáról írt. ${ }^{5} \mathrm{Az}$ értelmezők egyik tábora — közülük talán a legnevesebbek Motto — Clark, Lawall és Zwierlein - a sztoikus irodalomból is jól ismert Hercules-kép alapján a hőst az erények megtestesüléseként magyarázza, akinek bukását Iuno irigysége okozza. ${ }^{6} \mathrm{Ez}$ a felfogás lényegében az euripidési modell továbbélését látja a római múben; szerintük a darab első részét képező cselekmény és az őrültség között itt sincsen közvetlen összefüggés. A másik értelmezói tábor — élükön Jo Ann Sheltonnal és a kommentárszerzô Fitchcsel — nézetei szerint azonban Seneca egészen más úton jár, mint

${ }^{2}$ Wilamowitz próbálkozása, hogy H. őrültségét pszichológiai alapra vezesse vissza, nem sok sikerrel járt, és nem talált szakmai támogatásra. Euripides Herakles. hg. von U. v. Wilamowitz-Moellendorf. Berlin 1895. II.127. skk.

3 Greek Studies. Oxford 1946. 112.

${ }^{4}$ Ld. erről legutóbb magyarul: Jan Kott: Istenevők. Bp. 1998. 138-140. (1990) 1.

5 Gottfried Mader: Form and Meaning in Seneca’s „Dawn Song”, (H. F. 125-201). Act. Class. 32.

${ }^{6}$ A. L. Motto és J. R. Clark: Maxima virtus in Seneca's Hercules Furens, CPh 76 (1981) 101-117.; G. Lawall: Virtus and pietas in Seneca's H. F. Ramus 12 (1983) 6-26; O. Zwierlein: Senecas H. F. im Lichte kaiserzeitlicher und spätantiker Dichtung. Wiesbaden 1984. Szintén hasonló véleményt fogalmazott meg korábban: $O$. Edert: Über Senecas Herakles und den Herakles auf dem Oeta. dissz. Kiel 1909.; W. Schulze: Untersuchungen zur Eigenart der Tragödien Senecas. dissz.. Halle 1937. 32—49.; B. Marti: Seneca's Tragedies. A New Interpretation. TAPha 76 (1945) 223-225.; K. Anliker: Prologe und Akteinteilung in Senecas Tragödien. Bern 1960. 45-48.; C. J. Herington: Senecan Tragedy. Arion 5. (1966). 465.; J. Dingel: Seneca und die Dichtung. Heidelberg 1974. 54-56.; F. Caviglia: (szerk) L. Anneo Seneca. Il Furore di Ercole. Roma 1979. 70-83.; S. Timparano: Un nuovo commenta all' H. F. di Seneca nel quadro della critica recente. A\&R 26 (1981). 113-141.; V. Wurnig: Gestaltung und Funktion von Gefühlesdarstellungen in den Tragödien Senecas. Frankfurt 1982. 133-145.; K. Abel: Seneca. Leben und Leistung. ANRW 32.2 (1985) 757 sk.; G. Mader: i. m. 1-25. 
athéni elődje. ${ }^{7}$ Szerintük Hercules tettei és őrültsége között összefüggés van, a hôs felelós bukásáért.

Ez az írás ebben a vitában szeretne véleményt nyilvánítani, méghozzá egy olyan cselekményrészlet vizsgálatával, amely, úgy tûnik, eddig az érvek között nem kapott jelentôségének megfelelő figyelmet. Ez az elem Hercules alvilági útja, azaz utolsó athlosa, melynek sikeres befejezése után tér vissza a drámában családjához Thebaeba. Euripidésnél a részletnek koránt sincs olyan jelentősége, mint a római darabban. Természetesen a görög tragédiában is kiderül, hol jár Héraklés a cselekmény kezdetén, elvétve később is szó esik róla, de csak a 610-615. sorokban tárgya a színpadi beszédnek. Senecánál ezzel szemben a darab elsô szerkezeti egységének, a Hercules ôrülését megelőző (az 1-894. sorig terjedô) résznek a központi motívuma. Vezérmotívumként újra és újra felbukkan, minden szereplő beszél róla, kárhoztatja vagy ünnepli, de mindegyik megfogalmazza véleményét vele kapcsolatban. A következőkben azt igyekszem bizonyítani, hogy a római szerzőnél ez az alvilágjárás az egész tragikum átértelmezésének eszközévé válik.

Hercules katabasisáról először Iunótól hallunk a prologusban (46-63). Az istennő a hős összes előzô munkáját 15 sorban idézi fel, de jóval hosszabban beszél erről. ${ }^{8}$

\author{
Nec satis terrae patent: \\ effregit ecce limen inferni Iovis \\ et opima victi regis ad superos refert. \\ vidi ipsa, vidi nocte discussa inferum \\ et Dite domito spolia iactantem patri \\ fraterna. cur non vinctum et oppressum trahit \\ ipsum catenis paria sortitum Iovi \\ Ereboque capto potitur et retegit Styga? \\ parum est reverti, foedus umbrarum perit: \\ patefacta ab imis manibus retro via est
}

${ }^{7}$ J. A. Shelton: Seneca's H. F.: Them, Structure and Style. Göttingen 1978. passim; J. G. Fitch: Seneca's H. F. Ithaca, London 1987. különösen 22-43. Hasonlóan még: E. Turolla: L' H. F. di Seneca. Maia 6 (1953) 21-42.; M. Marcosignori: Il concetti di virtus tragica nel teatro di Seneca. Aevum 34 (1960) 217-233.; D. Henry, B. Walker: The Futility of Action: A Studie of Seneca's H. F.. CPh 60 (1965) 11-22.; J. T. Bishop: Seneca's H. F.: Tragedy from modus vitae. C\&M 27 (1969) 216-224.; H. J. Mette: Die Funktion des Löwengleichnisses in Senecas H. F.. WS 79 (1966) 477-489.; E. Paratore: Il Prologo dello H. F. di Seneca e l' Eracle di Euripide. Roma 1966. R. W. Tobin: Tragedy and Catastrophe in Seneca's Theater. CJ 62 (1966) 64-70.; W. H. Owen: Commonplace and dramatic symbol in Seneca's Tragedies. TAPhA 99 (1968) 291-313.; W. H. Friedrich: Die Raserei des Hercules. in: Senecas Tragödien (szerk. E. Lefèvre). Darmstadt 1972. 131-148.; C. Zintzen: Alte virtus animosa cadit. Gedanken zur Darstellung des Tragischen in Senecas H. F. in: Senecas Tragödien (szerk. E. Lefèvre). Darmstadt 1972. 149-209.; G. K. Galinsky: The Herakles Theme. Oxford 1972. 168-174.; G. Wellmann-Bretzingheimer: Senecas H. F. WS 91 (1978) 111-150.; J. G. Fitch: Pectus o nimium ferum: Act V of Seneca's H. F. Hermes 107 (1979). 240-248.; A. Rose: Seneca's H. F.: A Politico-didactic Reading. CJ 75 (1979/80) 135-42.; J. G. Fitch: Notes on Seneca's H. F. TAPhA 111 (1981) 65-70.; V. Sorensen: Seneca. München 1984. 236-40.

${ }^{8}$ A szöveget és a sorok számozását J. G. Fitch (1987) alapján közlöm. 


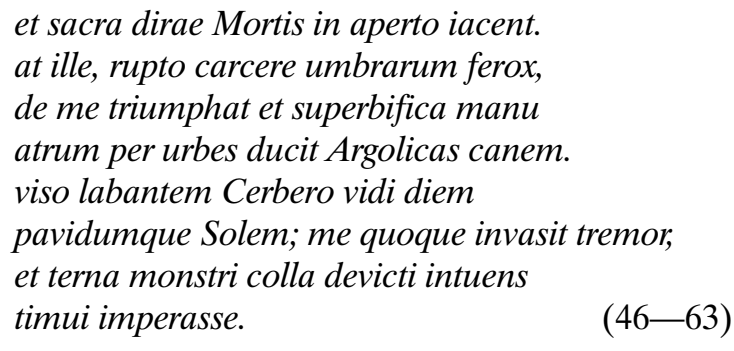

Az első interpretáció, Iuno interpretációja szerint tehát Hercules erőszakkal hatolt be a halottak birodalmába (effregit limen), erőszakkal kényszerítette rá annak urát, hogy átadja neki a Cerberust (Dite domito), amelyet hadizsákmányként hozott magával (opima, spolia). Még ezeknél is félelmetesebb azonban visszatérése az alvilágból, mert áttörte a halottakat az élőktől elválasztó határvonalat, és így nyitva áll az út a holtaknak az élók közé. Az egész világ rendje bomlott meg ezzel, ami félelemmel tölti el az isteneket. Jellemzó Seneca szerkesztése, hogy csak a szöveg legvégén derül ki, hogy éppen magától Iunótól kapta Hercules a megbízást minderre: (timui imperasse). A görög darabbal összehasonlítva Iuno személye sokkal fontosabb és egyénítettebb. Senecánál Eurystheus jelentősége háttérbe szorul (neve is csak egyszer hangzik el), és helyette előtérbe lép Iuno, tőle kapja a hős mindig újabb feladatait. Az istennő tetteit a szerelmi féltékenység és Iuppiter hútlensége miatti sértettség motiválja. Mindezek az érzelmek a Hercules elleni féktelen gyúlöletben csúcsosodnak ki. Így a regina deum az epikából, elsôsorban az Aeneisből és a Metamorphosesből jól ismert szerepben áll előttünk. Az sem jelent meglepetést, hogy a római irodalomban megszokott módon Iuno a megfontolással szemben a szenvedélyeinek engedelmeskedik, tetteit a furor irányítja, mint amikor Anchises fiának elpusztítására vihart támasztott a tengeren. Egyéniséget kap Seneca istennóje, és ez az egyéniség gazdagságát nem utolsó sorban a korábbi irodalom Iunó-figuráit idézô hasonlóságból nyeri. Nem meggyőzőek a Hercules morális felelősségét hangsúlyozó filológustábor azon képviselőinek nézetei, akik Iuno alakját szimbólumként, Hercules saját hybrisenek perszonifikációjaként értelmezik. ${ }^{9}$ Iuno a dráma autonóm személyisége.

A prologus és a kardal után Megara és Amphitryo jönnek a színpadra. Amphitryo hosszasan panaszolja fiának eddigi megpróbáltatásait (205-248). Beszámolójában éppen az ellenkezőjét tapasztaljuk annak, amit Iuno monológjában figyelemre méltónak láttunk: Amphitryo nem beszél az alvilágról sem hosszan, sem röviden. Először részletezve szól arról, hogyan próbálta elpusztítani az istennő már a gyermek Herculest, majd felsorolja fiának mind a tizenegy korábbi munkáját, de nem szól a legutolsóról, a jelen veszedelmei szempontjából legfontosabbról. Vajon

${ }^{9}$ Lawal: i. m. 135; Zwierlein: i. m. 22 sk. 
miért nem említi az alvilági utat? Miért a hallgatás? Természetesen tudnia kell, hol van a fia (vagy nevelt fia): szövege végén kijelenti: aderit... et ad astra emerget; inveniet viam aut faciet (276 sk.). ${ }^{10}$ Az emergere hallatán Megara magához ragadja a szót. A szerelmes asszonyban nem kelt félelmet kimondani azt, amit Amphitryo nem akar vagy nem mer. Ó nem habozik férjének küldetésérôl beszélni. Elragadtatott hangú beszéde ellentétben áll Amphitryo higgadtan méltóságteljes fogalmazásával. Hangvétele inkább Iunót idézi.

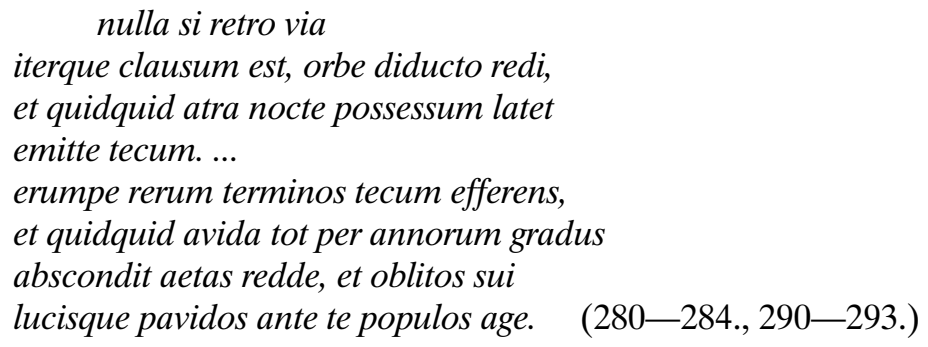

Megara tehát ugyanazt emeli ki, amit Iuno: a visszatérés erôszakosságát, és a holtak visszavándorlását az élő́k közé, csakhogy mindez az ô interpretációjában pozitív értéket nyer. A két női szereplő indulata természetesen ellentétes tartalmú: az egyiké az elvakult gyúlölet, a másiké a szenvedélyes szerelem, de beszédükben mégis meghökkentően sok a közös vonás. Megara is éppúgy az alvilág királyától szerzett spoliaról beszél, mint az istennô. A két szereplő hasonlítását félreérthetetlenné teszi néhány szöveghely is: levia sed nimium queror (63) - mondja Iuno, magna sed nimium loquor - panaszolja Megara (295). A következményekkel nem törôdve biztatta Iuno a hőst, hogy lemenjen az alvilágba, Megara pedig éppígy tüzeli férjét a viszszatérésre. Seneca párokba rendezi el a darabban megjelenó jellemeket. Ezeket a párokat a hasonlóság és az ellentétesség dialektikája tartja össze, ahogyan Iuno és Megara példája mutatja. A két női szerepló érzelmei ellentétesek egymással, de az a benyomásunk, mintha jellemzésükben fontosabb lenne ennél az a tény, hogy az indulat uralkodik ôrajtuk és nem ôk azon.

Amint Hercules visszatér és elôször megjelenik a színpadon, ő is rögtön alvilági útjáról és a nap világára felhozott Cerberusról beszél retorikusan feldíszített, fellengzôs mondatokban (592-615): a keresett választékossággal külön-külön megszólított istenek jobban teszik, ha eltakarják arcukat, nehogy beszennyezze látásukat az alvilági sötét zugából akarata ellenére a napsütötte földre vonszolt fenevad. Hoc nefas cernant duo, | qui advexit et quae iussit. (603 sk.). Ez a darab egyik legérdeke-

${ }^{10}$ Persze az ad astra emergere kifejezés nem egyértelmú, ebben a kontextusban vonatkozhat $\mathrm{H}$. visszatérésére az alvilágból, de ugyanakkor betú szerint olvasva jelentheti $\mathrm{H}$. ascensióját a várt és remélt apotheózisa során. 
kesebb és legproblematikusabb jelenete: Elgondolkozhatunk a szinpadi ábrázolhatóságán anélkül is, hogy belebonyolódnánk a könyvdráma — színpadi mú ôsrégi, parttalan és mára már némiképp értelmét vesztett vitába. Nem az a kérdés a legfontosabb ugyanis, vajon a Nero-kori szerzô színpadra szánta-e darabjait, és vajon valóban előadták-e ôket a korszakban, hanem az, vajon ma elóadhatóak-e, előadhatónak érzik-e a színházi szakemberek és a közönség. ${ }^{11}$ Hogyan kell ugyanis elképzelnünk ezt a jelenetet? Magával hozza Hercules a Cerberust vagy sem? Ha magával hozza, mi történik vele a szónokiasan patétikus belépő után. Ottmarad a színpadon a további cselekmény alatt és senki sem törődik vele, vagy csendben kisomfordál a színrôl, egyszerúen elpárolog, és többé elő sem kerül? Ez nyilvánvalóan lehetetlen márcsak azért is, mert a prologus egyik sorából (59.) valószínúleg arra következtethetünk, hogy Hercules Argosban hagyta a ,jószágot”. ${ }^{12}$ Legmeggyő́oóbbnek az tûnik, hogy nincsen semmi nála a buzogányán és az oroszlánbőrön kívül, nyoma sincs a Cerberusnak. Így viszont valami disszonancia kíséri a hős belépőjét, sốt azt is mondhatjuk, hogy a jelenetnek a színpadon óhatatlanul kissé komikus hatása van. Miért inti ilyen nagy beleéléssel éppen ekkor az isteneket arra, hogy óvatosak legyenek a nézelődéssel, amikor már több napja az anyaföld hátán van a szörnyeteg, és már végigijesztgette vele Argos városait (vö. 59.)? Az üres kézzel előadott, istenekhez címzett intelmek felvillantanak valamit a pl. az Alkéstisből jól ismert, mosolyra ingerlő $\mu \varepsilon \gamma \alpha \lambda$ $о \rho \eta ́ \mu \omega v$ (magniloquus) hősből. Eredeti kérdésünk, azaz Hercules alvilágjárásának megítélése szempontjából a beszédből nyilvánvalóan a nefas szónak van kiemelkedő jelentősége. Nemcsak Iuno elfogult értelmezése szerint volt tehát nefas az alvilági lényt a nap fényére kényszeríteni. Maga a hôs is hasonlóan értelmezi utolsó athlosa eredményét. Ennek következtében azonban alapvetôen más helyzetben van, mint Euripidés tragédiájának a hőse.

Alig kezdôdik el - mintegy 600 soros elókészítés után — a valódi drámai cselekmény a színpadon, Hercules megismeri a családját fenyegető veszélyt, és azonnal indul, hogy leszámoljon a zsarnok Lycusszal, amikor ismét megállítja az eseményeket Theseus elbeszélése. ${ }^{13}$ Bár Seneca tragédiáiban nemritkák a dráma kereteit szétfeszítő és kétségtelenül az epikus múnemmel versengő beszámolók, Theseus beszámolója az alvilágról még a senecai drámák világában is meglepően hosszúra nyúlóan részletező. ${ }^{14}$ Nem előre halad a cselekmény, hanem alighogy lendületet vett, ismét visszafordul.

11 J. Barish: The Anti-Theatrical Prejudice. Berkeley, Los Angeles 1981.

${ }_{12}$ Euripidés Héraklése Argosban hagyja a Kerberost Hermionénál, amíg el nem tudja vinni valahová: 614 sk.; 1386 sk. Seneca nem beszél a Cerberus további sorsáról ennyire egyértelmúen.

${ }^{13}$ Euripidésnél csak a darab végén jelenik meg Th., hogy magával vigye H-t a megtisztulást ígérő Athénba. Senecánál viszont egyszerre érkezik meg a két hérós, a változtatásra elsősorban a beiktatott elbeszélés miatt volt szükség.

14 Theseus beszámolója legközelebbi rokonságot az Agamemnon hírnökének, Eurybatesnek az elbeszélésével mutat (421—588). 
Az egész beszámoló dramaturgiai helyzete először erőltetettnek és érthetetlennek túnik ${ }^{15}$ : éppen csak hazaérkezik Hercules, a család váratlanul megmenekül az életveszélyból, a zsarnok trónbitorló elnyeri megérdemelt büntetését, és ekkor, a darab elsố drámai csúcspontján, amikor egész sereg fontos és a szereplôket közvetlenül érintő kérdés vár választ (mi történik Lycusszal, hogyan zajlik le a küzdelem közte és Hercules között, vajon akad-e valaki a zsoldosok között, aki kiáll a zsarnok mellett stb.), Amphitryo, ahelyett hogy örömének, megkönnyebbülésének engedne utat, esetleg megfogalmazná aggodalmát az éppen zajló események miatt, azt kéri Theseustól, meséljen arról, mi történt az alvilágban. Theseus pedig hosszadalmas és a helyzethez nem egykönnyen illeszthetô elméletiességgel kezd beszélni arról, hogyan van berendezve az alvilág. Az első pillanatban úgy túnik, Amphitryo kérdése és a válaszul kapott beszámoló nem illeszkedik valami szervesen a drámai szituációba. Mintha csak meróben külsőleges ürügy lenne arra, hogy a költố egy nyilvánvalóan Vergiliusszal versengő leírást illesszen a cselekménybe. Kétségtelen, hogy az epikus jellegú elbeszélés túlzott hosszúságúra dagad, s ha a dramaturgiának nem használ is, elhelyezése korántsem erőltetett vagy céltalan. Ez alkotja a záróelemét a dráma elsô részének, amelynek vezérmotívumát az alvilági kalandban találtuk meg. A különböző szubjektív vélemények után, melyek annak alapján különböztek egymástól, ki milyen érzésekkel viszonyul egyébként Herculeshez, ekkor halljuk meg a hitelesnek tûnő beszámolót a szavahihetô szemtanútól. Most kapunk egyben választ arra a kérdésre, amelyet a imént tettünk fel, hogy ti. miért nem beszél Amphitryo az utolsó erópróbáról, aki pedig Hercules korábbi munkáit leplezetlen elégedettséggel sorolta fel. Ha az eddigieket megfontoljuk, érthetővé válik az is, miért akar Amphitryo az elsố adódó alkalommal éppen erról hallani. Azért nem volt hajlandó az apa a dráma elején a fia által meghódított alvilágról beszélni, mert józan tudatával pontosan tisztában volt az utolsó athlos istensértő lényegével. Az erószakos behatolás a holtak birodalmába nem olyan cselekedet, amelyre Amphitryo apaként büszke lehetett volna. Nem akart szót ejteni róla, amíg kétséget kizáróan nem derítette ki, mi történt valójában Dis palotájában. Amphitryo az a szereplője a drámának, aki Hercules iránti szeretete ellenére megórzi helyes emberi viszonyát az eseményekhez. Nem azért képes uralkodni indulatain, mert azok hiányoznak vagy erőtlenek, hanem mert a helyes mértéket követô gondolkodás szüntelen ellenőrzés alatt tartja ôket, és így ellentétben áll a Iuno és Megara esetében megfigyelt magatartással.

Az apa hosszan engedi beszélni Theseust, feltesz neki néhány udvariasan banális kérdést, mint pl., vajon van-e szőlootermesztés és mezőgazdaság az alvilágban,

15 V.ö. Lessing kétes méltatását: „Endlich aber ... fängt er eine lange und prächtige Beschreibung an, welche an einem jeden anderen Orte Bewunderung verdienen würde." Von den lateinischen Trauerspielen welche unter dem Namen des Seneca bekannt sind, in Sämtliche Werke, hg. K. Lachmann és F. Muncker. Stuttgart 1890. 179. 
vagy hogy vajon a búnösök megbüntetése egyetlen helyen zajlik-e le. Az egész beszámoló lényegében a vergiliusi leírás olykor kisiskolás felmondása. ${ }^{16}$ Theseus ugyanis nem válaszol az aggastyán kérdésére. Mellébeszél. Úgy tûnik, neki sem könnyú arról beszélnie, amit az apa hallani akar. Amphitryo nyilvánvalóan nem arra kiváncsi, milyen az alvilág hely- és vízrajza, kérdése félreérthetetlenül arra vonatkozott, mit csinált Hercules az alvilágban. Erre a kérdésre viszont vonakodik válaszolni Theseus. Kitérô válaszában funkciót nyer az irodalmi toposz: mindenki számára jól ismert képek és jól ismert információk hangzanak el a színpadon illusztrálva Theseus tapintatát és helyes ítéletét. Ő is szívesebben hallgatna, mint az apa a darab elején. Ha hasonlóságot találtunk a két nôi szerepló szenvedélyes elfogultsága között, Theseus és Amphitryo hasonlóságát sem hagyhatjuk észrevétlenül. ${ }^{17}$

Végre ismét felteszi az öreg azt a kérdést, amelyik valóban foglalkoztatja, ami miatt az alvilágban történtekre terelte a szót:

nunc ede nati nobilem pugnam mei. (760.)

és végül a leginkább izgató kérdést:

partui volentis munus an spolium refert? (761.)

Iuno és Megara már a darab elején spoliumról beszéltek, az apa azonban itt mondja ki először a szót, mert mindvégig reménykedett, hogy a Cerberus foglyul ejtése az istenség megsértése nélkül is sikerülhetett. A kérdésre adott válaszban megváltozik Theseus beszámolója: míg az eddigieket tudatos vergiliusi reminiszcenciák jellemezték, ettől kezdve éppoly megfontolt ellentét az Aeneisszel hívja fel magára a figyelmet. Theseus elmondja, hogyan kényszerítette Hercules puszta erószakkal Charont arra, hogy csónakjába vegye és a Lethe túlsó partjára vigye. A Vergiliust csak felületesen ismerő olvasónak is önkéntelenül felötlik, milyen könnyú dolga van a pius Aeneasnak (illetve Sibyllának), amikor az aranyág segítségével akarja jóindulatra

${ }^{16}$ Néhány példa: Ugyanúgy hasonlat érzékelteti az alvilágra szállás félhomályát, mint az Aeneisben: vö. H.F. 671 sk. - Ae. 6. 270 skk.; a lefelé vezetố út könnyúségérôl és a visszavivố férfit próbáló fáradságáról v.ö. H.F. 675, 678 sk.; a bejárat mellett álló fáról, melyen a hamis álmok és riasztó szörnyek tanyáznak v.ö. H.F. 690-696 - Ae. 6. 282 skk.; Dis palotájáról: H.F. 709 skk. - Ae. 6.549 skk. stb. Vergilius mellett fontos forrásként feltétlenül meg kell említeni Ovidius Metamophosesének 4. énekéból Iuno rövidebb katabasisát (432-512).

${ }^{17}$ Seneca, hogy Theseust Herculeshez mélyen kötődő, ámde a helyes emberi mértéket szakadatlanul megőrző figuraként mutathassa be, mélyen hallgat arról, hogyan került a hérósz az alvilágba. Csak egyszerúen arról értesülünk, hogy fogságban volt ott, és H. hozta ôt ismét az emberek világába. A Proserpina elrablására tett kísérletről nem akar tudni Seneca. 
hangolni a mitikus révészt. ${ }^{18}$ Ugyanez ismétlődik meg a Cerberus esetében is: az eposzban Sibylla varázsszerekkel elaltatja (6. 417-423), míg Hercules buzogányát forgatva folyamatosan ütlegeli (verbere assiduo rotat, 801), amíg engedelmessé nem válik a szörny.

A beszámoló nyomán az apa alighanem beigazolva látja félelmeit: fia csak úgy tudta Iunótól kapott feladatát teljesíteni, hogy közben megsértette az alvilág isteneit. A hős megérkezését közvetlenül megelőző kardal szintén alvilágjárásról szól, de nem Herculeséről, hanem Orpheuséról. A dalnok képes volt múvészete segítségével megindítani az alvilági isteneket, és Dis önként visszaadta a dalnoknak elveszített kedvesét, olyan feltételek kíséretében, melyeket ô maga szabott meg. A kar elbeszéléséből kiderül az olvasó számára, hogy Eurydice visszatérése anomáliát és nem a törvények megsemmisítését jelentette. Azaz jelentette volna, ha nem maga a feltétel lett volna az alvilági uralkodó ajándékába belerejtett biztosíték arra, hogy az élők és a holtak rendje zavartalan maradjon. Quae vinci potuit regia carmine, / haec vinci poterit regia viribus (590 sk.) - hangzanak a kar utolsó szavai. Vajon figyelmen kívül hagyhatjuk-e a különbséget? Orpheus múvészetével megszolgálta Eurydicét, Hercules erőszakkal hurcolta magával a Cerberust. Hercules megsértette az alvilág urát. Nem búntelen. Ez a summája Theseus elbeszélésének is, melynek sem szavahihetôségét, sem jóindulatát nincs okunk kétségbe vonni. Nem állíthatjuk tehát, hogy Hercules bukása és tettei között nincsen közvetlen összefüggés. Az utolsó bizonyítéka ennek a tézisnek az elpusztított gyerekeket sirató kardal:

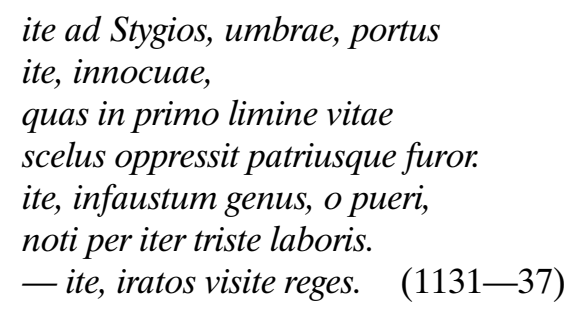

Engesztelő áldozatok a halott gyerekek a haragos isteneknek. Haláluk és apjuk alvilági útja között szoros összefüggés van. Hercules élve hagyta el a halottak birodalmát, helyette kell a gyerekeinek visszamenniük.

${ }^{18}$ A jelenet nyilvánvalóan Vergiliuszéval folytat dialógust: 1. (hasonló elem): Charon felszólítja a Styx vizéhez közeledó idegent, hogy álljon meg Ae. 389.: Fare age, quid venias; iam istinc et comprime gressum. HF. 772.: Quo pergis audax? siste properantem gradum. 2. (ellentét): Ae. 407-410. Charon az aranyág látványától megenyhül: Tumida ex ira tum corda residunt. HF. 773-775. H. kiveszi a révész kezéből a csáklyát és azzal kényszeríti: non passus ullas natus Alcmena moras/ ipso coactum navitam conto domat/ scanditque puppem. 3. (hasonló elem): a beszálló (Aeneas, ill. Hercules) súlyától a szokásosnál jobban lesüllyed a csónak és víz megy bele: Ae. 413 sk. gemuit sub pondere cumba/ sutilis, et multam accepit rimosa paludem. HF. 776. cumba populorum capax / succubuit uni; sedit et gravior ratis/ utrimque Lethen latere titubanti bibit. 
Hercules erőfeszítésének eredménye a nefas, istensértő cselekedet, mely egészében az isteni és az emberi világ rendje ellen irányul. Nem egyszerúen értelmetlen tett az alvilág kutyáját az emberi világba cipelni, hanem ellentétben áll mindazzal, amit a hôs korábbi harcai céloztak. Hercules mint alexikakos dolga éppen az lenne, hogy védelmezze az emberi világot; korábban szörnyektől szabadította meg a földet, s most pedig íme éppen ô az, aki új szörnyet szabadít rá. Hercules alvilági teljesítményével saját korábbi tetteinek tagadását alkotta meg: önnön ellentétébe fordult. Ez a legfontosabb változtatás, melyet Seneca az Euripidéstől kapott mintán végrehajt. A római tragédiából hiányzik az igazi peripeteia, a darab elsố része az őrület miatt bekövetkező tragédiának a baljóslatú elókészítése. A görög dráma tragikuma abból fakad, hogy a cselekmény két része között nincsen egyenes összefüggés, logikai egységet az események között csak az istenek rosszindulatú irigysége teremt. Seneca - ahogyan hasonló jelenséget nemegyszer megfigyelhetünk a görög múvek római adaptációin - megteremti a cselekmény részeinek dramaturgiai, kauzális és pszichológiai egységét. Ennek eredménye azonban egészében eltérő tragikum.

Mikor kezdődik tehát Hercules ôrültsége? Biztosan a dráma ideje előtt. Az a hős, aki az alvilágból visszatért, már túllépett az emberlét normáin és szabályain. Utolsó munkája a virtus öncélú fitogtatása: indomita virtus colitur (39). Mindez nem azt jelenti, hogy Hercules tetteiben az alvilági „munka” fordulópontot jelentene. A dráma szövege alapján aligha lehet meghatározni, mikor hagyja cserben Herculest egészséges érzéke, mikor válik először csak megszállottá, majd őrültté. A holtak között tett útja nem kiváltója a gondolkodás zavarának, hanem bizonyítéka. Úgy túnik, a rendkívül heterogén Heraklés-mítoszból, melyben korántsem csak a hősiesség kap szerepet, Seneca darabjában (Euripidéstốl egészen eltérő módon) megjelenik a hôsitôl igencsak eltérő Héraklés-hagyomány is, az általa bemutatott jellem az alvilágjárás „teljesítménye” nélkül is sokkal ellentmondásosabb, mint a görög forrásmunkában. ${ }^{19}$

Hercules ôrjöngése a darab 939. sorában kezdődik, de azon a helyen csak a tudatzavar külsố jelei jelentkeznek, zavaros tudatállapota átcsap hallucinációba. Hercules színpadi megjelenésétől kezdve úgy beszél és cselekszik, hogy nehéz ép tudatot feltételeznünk. Csak a legvilágosabb példákat idézem: ${ }^{20}$ Elsố monológjában kijelenti:

${ }^{19}$ Lycus említi például azt az esetet, amikor H. női ruhában Omphalénál időzött, és megerőszakolta Eurytus lányait. A. nem is tud mással replikázni a vádra, mint azzal a kevéssé meggyőző érvvel, miszerint gyakran előfordul más hősökkel is, hogy a nagy teljesítmények után „elengedik magukat” (465-88). Később egy kardal utal arra, hogy H. már korábban, Pylos ostrománál szentségtörő módon megsebesítette Dist (862-867).

${ }^{20} \mathrm{H}$-nek az isteneket sértố megnyílvánulásainak teljesebb számbavétele Jo Ann Sheltonnál: i. m. 62-67 és Fitch: i. m. (1987) 24-28. 


\author{
si placerent tertiae sortis loca, \\ regnare potui. noctis aeternae chaos \\ et nocte quiddam gravius et tristes deos \\ et fata vici; $\quad(609-612)$
}

Ezt a gondolatot, miszerint Hercules könnyúszerrel elfoglalhatta volna nagybátyja trónusát az alvilágban, ha úgy hozta volna kedve, nehéz másképpen magyarázni, mint hybrisszel, illetve az egyéni korlátok félreismerésével. Hercules az erő bajnoka és nem az önismereté, emberi normákat felülmúló teljesítménye fizikai természetú, melyhez nem társulnak ezzel arányos spirituális készségek.

Lycus megölése után vértől szennyes kézzel lép az oltárhoz, hogy áldozatot mutasson be, Amphitryo figyelmezteti, de nem hallgat rá, hanem véres kézzel kezd hozzá az áldozathoz (919-924). ${ }^{21}$

Euripidésnél Iris és Lyssa megjelenése és az általuk a hősre bocsátott őrület valódi sorsfordulatot hoz. Senecánál azonban az egyetlen isteni megnyilvánulás a prológusban található, késóbb nem történik közvetlen isteni beavatkozás a cselekménybe. Amit a színpadon látunk, egyetlen előrehaladó folyamatnak a pszichológiailag jól motivált állomásai. Seneca homérosi (de a görög drámák többségéből is) jól ismert kettős motívációt alkalmaz: az istenek aktivitása és az emberi világ logikailag koherens eseményei egymást kiegészítve, kétszeresen is indokolják az eseménysort. Kettős motiváció, mert mindkét tényező önmagában is elégséges lenne a történés magyarázataként. ${ }^{22}$ Hippolytos halálát például megmagyarázza az emberi dráma Aphrodité bosszúja nélkül is. A bevezetôben elmondottakból vélhetôleg egyértelmúen kiderült, hogy a Héraklés mainomenosban Euripidés lemond ennek a kettős motivációnak az alkalmazásáról: ha elvesszük cselekményéből az istenek szereplését, tökéletesen értelmezhetetlen, illogikus eseménysort kapunk. Seneca másfajta, a görög mintától eltérő tragikuma éppen a kettős motiváció felelevenítésén alapul. Hercules szavaiban kezdettől ott rejtőzik az őrület, a 939. sorban a zavart tudatállapot fokozódik csupán pathologikussá. Iuno beavatkozása nélkül is értelmezhetô a cselekmény. Azzal, hogy a költő a prologusra szorítja az istennő megjelenését, és elődjétől eltérően nem engedi megnyilvánulni az istenvilágot az őrültté válás pillanatában, önmagában is elótérbe állítja az emberi drámát és redukálja az isteni jelenlétet.

Ezzel a megállapítással egyenertékú az is, hogy az okság, azaz a felelősség kérdése sem választható ketté Senecánál istent, illetve embert terheló részre. Ez az a pobléma, amelyet szintén igen eltérô módon ítélnek meg a különböző szembenálló táborokhoz tartozó kutatók: egy részük teljes egészében Iunóra hárítana minden felelősséget, másikuk éppen ellenkezőleg, hajlamos annak alábecsülésére. ${ }^{23}$ Amphit-

${ }^{21}$ V. ö. Fitch: i. m. (1987) 27.

${ }^{22}$ H. D. F. Kitto: Sophocles, Dramatist and Philosopher. London 1958. 42-64.

${ }^{23}$ Jellemző példaként álljon itt Lawall véleménye (i. m. 10.): „The crime is Juno's... Hercules is not to blame; it was a mere error on his part, not a culpable crime (scelus); ultimately it is Hercules' fortuna that is to blame." 
ryo a darab elején arról panaszkodik, hogy Iuno szüntelen parancsaival üldözi nevelt fiát: alighogy véget ért az egyik megpróbáltatás, kezdődik a másik: nec ulla requies, tempus aut ullum vacat $\mid$ nisi dum iubetur. (213. sk.). A dráma cselekménye azonban nem igazolja mindenben az apa által rajzolt képet. Bonyolult viszony alakul ki a feladatot adó istennő és az azt teljesítő hős között. Iuno mindig nehezebbet, lehetetlenebbet kíván, Hercules pedig fontolgatás nélkül mindig engedelmeskedik, bármi legyen is a kívánság. Az egész rendszer mechanikus és önmagát gerjesztő. Végül Hercules teljesen azonosul azzal a szereppel, melybe először talán valóban csak az istennố féltékeny haragja kényszerítette. Ez az azonosulás elkerülhetetlen következménye a kettôs motivációnak: a külsô ösztönzés belső kényszerré válik. Iuno gyúlölete láthatatlanul jelen van az egész történet során, de egyszer sem manifesztálódik: Hercules látszólag külső behatás nélkül cselekszik. Egy sor olyan momentum is felhívja magára a figyelmet, mely rávilágít Herculesnek önmagáról kialakított képére, és eligazítóak lehetnek az isteni ráhatás - emberi felelősség kérdéskörében is. Hazaérkezése után, amint meghallja, mire készül Lycus, belső kényszert érez arra, hogy azonnal, másodpercnyi késedelem nélkül ellensége felkutatására induljon: ad hauriendum sanguinem inimicum feror (636). Arra sincsen ideje, hogy visszatérése örömére megölelje családját: differ amplexus parens | coniunxque differ (638 sk.). Nincsenek közvetlen veszélyben azok, akiket szeret. ${ }^{24}$ Miért a sietség? A hős úgy érzi, elsődleges feladata a bosszú, a megtorlás, az ellenség elpusztítása. A senecai Hercules-figura személyiségét egyetlen indulat foglalja el, ennek megfelelóen az meglehetősen egysíkú: ösztönösen hívja a harc (feror), de elhárítja az érzelmi közeledést: az nem az ô világa. A darabban Hercules részéról hiányzik minden fizikai gesztusa a családi összetartozásnak. Az ekkor elhalasztott ölelésre később sem kerül sor, Hercules nem érinti meg családtagjait, csak gyilkos kézzel. Megarát meg sem szólítja az idézett imperativuszon kívül egyetlen alkalommal sem. Lycus megölése után, a színre visszaérkezve sem fordul családja felé, hanem Iuppiternek kezd áldozatba, és közben meghökkentő dolgokat mond. Pszichológus számára könnyen elemezhetố esettanulmány: elpusztítással fenyegeti mindazt a természetben és az emberi világban, amit ellenségesnek ítél, mindazt, ami az általa kívánt rendbe nem illik bele: féljen a villám, a mérgező növények, és a bárhol is létező véres zsarnokok. Hercules végérvényesen rendet akar tenni a világban (927—939).

si quod etiamnum est scelus latura tellus, properet, et si quod parat monstrum, meum sit.

${ }^{24}$ Ebben a tekintetben is eltér egymástól Euripidés és Seneca darabja. Euripidésnél Lykos végezni akar Héraklés hozzátartozóival, már halotti ünnepi ruhában az áldozati máglya elôtt állnak, amikor megérkezik a hôs az utolsó pillanatban. Ezzel szemben Senecánál Lycus arra akarja kényszeríteni Megarát, menjen hozzá feleségül, fenyegetése nem közvetlen, valamikor a meghatározatlan jövő́re vonatkozik. 
Újabb bizonyítékával az azonosulásnak akkor találkozunk, amikor őrült rohamából magára eszmélve felfedezi maga mellett gyerekei és felesége holttestét. Érdemes a szöveget hosszabban idézni:

Quod cerno nefas?

nati cruenta caede confecti iacent, perempta coniunx. quis Lycus regnum obtinet, quis tanta Thebis scelera moliri ausus est Hercule reverso? quisquis Ismeni loca, Actaea quisquis arva, qui gemino mari pulsata Pelopis regna Dardanii colis, succurre, saevae cladis auctorem indica. ruat ira in omnes: hostis est quisquis mihi non monstrat hostem.

Hercules bizonyos szempontból hasonlóan viselkedik itt, mint hazaérkezésekor. Akkor az örömnek kellett várnia, míg beteljesíti a bosszút, itt a gyászra nincsen idő éppúgy a bosszú miatt. differ amplexus (638) - mondta az előbbi helyzetben, differte fletus (1175) - így az utóbbiban. Egyetlen szava sincsen a veszteség fájdalmának kifejezésére, harcosi tekintélye foglalkoztatja: ki merészelt ilyet tenni annak ellenére, hogy ő is jelen van. Maga mellett látja családja véres tetemét, és egyetlen jajszó nem hangzik el szájából. Rögön ellenséget keres, bosszút készít, fenyeget. Az érzelem nem az ô világa. Az azonosulás a harcosi szereppel nem is lehetne tökéletesebb: egyetlen dolgot érez maradéktalanul saját feladatának, a harcot. Ennek fényében persze másképp — árnyaltabban — láthatjuk Iuno szerepét és a felelősség problémáját is. Amphitryo említett panasza a darab elejéról, amelyben mindenért Iunót okolja, többet árul el az apa személyérool, mint Herculesről. Alcides megpihenésének fô akadálya a darab cselekményének idején már nem Iuno újabb és újabb parancsa, hanem saját maga.

Nem nehéz meglátni a motivációt, mely Amphitryo fiát örökös harcra készteti: virtusa segítségével az istenek közé akar emelkedni. Végre el akarja érni a már régen kilátásba helyezett halhatatatlanságot. Seneca ezzel összefüggésben olyan belső késztetést is sejtet, mely nem olyan nyilvánvaló, mint az előbbi, de kétségtelenül ott rejlik a szövegben, ez pedig az apaság kérdése. Euripidésnél fel sem merül, hogy bárki - beleértve Lykost is - kétségbe vonná Zeus apaságát. A római drámában ezzel szemben Lycus egyértelmúen tagadja Hercules égi származását: Quo patre genitus caelitum spert domum? (438) ...mortale caelo non potest iungi genus. (448) De felmerül a kétség Iuno prologusában is: dum nimis saeva impero | patrem probavi... (35 sk.). Herculesnek tehát virtusa segítségével bizonyítania kell olymposi származását. Virtusa eszköz, a bizonyítás és istenné emelő érdemek megszerzésének eszköze. Nem kerülhetik el figyelmünket Hercules és Lycus sok tekintetben rokon vonásai. Ellentétei és ugyanakkor ismétlései egymásnak. Lucus számára szintén eszköz a 
virtus, mellyel rangot akar elérni: nobiles non sunt mihi avi $\mid$ nec altis inclitum titulis genus, | sed clara virtus. (338 skk.) Miként Lycus az emberi hierarchia aljáról a tetejére akar emelkedni a virtusa segítségével, ugyanúgy akar annak tetejéról az istenek világába emelkedni Hercules. A darabban megnyilvánuló legkeserúbb irónia, hogy Lycus cinikus szavai, melyeket Megarának mond, amikor az számon kéri rajta hozzátartozói hidegvérú lemészárlását, éppen Hercules történetében válnak valósággá a színpadon:

$$
\begin{aligned}
& \text { cruento cecidit in bello pater? } \\
& \text { cecidere fratres? arma non servant modum; } \\
& \text { nec temperari facile nec reprimi potest } \\
& \text { stricti ensis ira; }
\end{aligned}
$$

Az utóbbi mondat emblémaszerú tömörséggel fogalmazza meg Hercules drámájának is a pszichológiai realizmussal felfogott lényegét.

Mit jelenthet a virtus, ha egyformán használható Lycusra és Herculesre? Nem sokat. Prosperum ac felix scelus | virtus vocatur (251 sk.) - véli Amphitryo, és természetesen Lycusra gondol. De vajon mit jelent Hercules virtusa, ha abban nyilvánul meg, hogy a Cerberust felhozza az alvilágból? Nem többet, mint féktelen harcivágyat, öncélú erőpróbát és szakadatlan készenlétet a vérontásra. Seneca itt látható módon a virtus szó két jelentését használja fel, és szembeállítja egymással a filozofi-

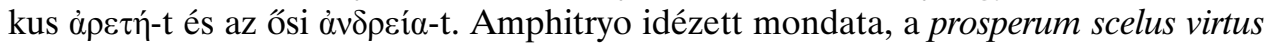
vocatur nyilvánvalóan az ellentétre épül, márpedig a scelus ellentéte nem az andreia,

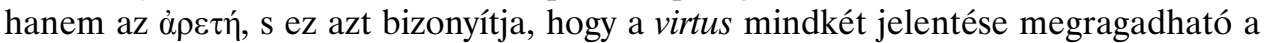

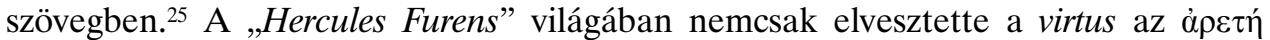
jelentését, s maradt belőle egyszerúen àvopeía, tartalma tovább silányult egészen a fortitudo-ig vagy akár a vis-ig. A virtus szónak ugyanis minden jelentéskörében pozitív

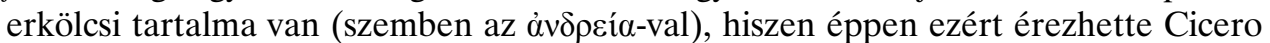
alkalmasnak arra a szót, hogy a görög filozófiai múvek adaptációiban az areté latin megfelelőjeként használja. ${ }^{26}$ A római számára olyan fontos fogalom a Seneca tragicus számára kiüresedett, nem több, mint ürügy és mentség bármiféle erőszakos tettre. A szomorú ítéletet inspiráló élményvilágot könnyen levezethetjük a költő tapasztalataiból, melyeket az egymás utáni princepsek mellett szerzett, akik rendre megistenülve már életükben nem érezték magukat az emberi világ részének.

Jo Ann Shelton a darabról szóló dolgozatában úgy véli, a legfontosabb és a legnehezebb feladat a darab végén még Hercules elôtt áll: meg kell tanulnia a jövôben, hogyan kell virtusán uralkodnia, hogyan kell azt helyesen használnia. De vajon létezik-e még bármilyen jövő is Seneca Herculese számára? Szerintem nem, leg-

${ }^{25}$ W. Eisenhut: Virtus Romana. München 1973. 149-152. A szerző másképp látja a kérdést, szerinte Seneca tragédiáiban: „die philospohische virtus sucht man vergebens, dagegen herrscht die Bedeutung „Tapferkeit”, „Heldenmut” ausschließlich.” (150).

26 V. ö. Eisenhut: i. m. 15. sk. 
alábbis emberi jövő nem. Visszavonhatatlanul elhagyta az emberek világát, de nem érkezett meg az istenekébe. Számára nincsen visszaút. Az emberek és istenek közötti senkiföldjén bolyong. Euripidés drámájában Héraklés visszatalál az emberi világba. Sokszor elemzett és vitatott monológjában megtagadja a gonosz és irigy isteneket, hogy gyászában ismét egészen emberré válhasson. ${ }^{27}$ Seneca darabjának hőse ezt már nem teheti meg. A görög tragédiában az istenek ölték meg Héraklés családját az ô karját és erejét felhasználva, Senecánál ő maga teszi ezt meg. Amphitryo csak azzal a fenyegetéssel tudja ôt visszatartani az öngyilkosságtól, hogy előbb végig kell néznie, amint ô, az apja is véget vet az életének. Ezt nehezen értékelhetjük visszatérésnek az emberi világba. ${ }^{28}$ Euripides Héraklése felismeri az univerzum személytelenségét és ezzel együtt amoralitását is, és tudatosan az embert választja mint egyetlen olyan lényt, amely meggyőződése alapján különbséget tud tenni jó és rossz között. Seneca hőse nem változik, sem személyisége, sem tudása nem alakul át; neki nehezebb dolga van, nem a világegyetemben, hanem saját magában kellene felismernie bukásának okait. Belátnia, hogy viszonya a valósághoz, a természethez és saját maga emberlétéhez alapvetốen elhibázott. Ez az a nehéz feladat, amellyel meg kellene birkóznia, de ehhez Hercules ereje sem elég.

A darab első kardalában arról énekel a kórus, hogy csak az olyan ember élhet boldogságban, aki nem vágyik mindig többre, mint amit a sorsa juttatott neki, megelégszik a szerény otthonnal, nem keresi a hatalmasok társaságát, nem hajszolja a politikai sikert, mely esküdt ellensége a nyugodt álomnak. Ebben a világban is jelen van a labor (137), de az nem a herculesi hőstettek kínnal teli erőfeszítése, hanem a köznapi élet megkívánta áldozat. Annak is jelen van az életében a cura (138), aki reggel állatait tereli legelni, madarat fog az erdőben vagy feszült figyelemmel várja, mikor rezdül meg horgászbotján a zsineg. Ez a cura azonban nem teszi tönkre a lélek nyugalmát. ${ }^{29}$ Novit paucos secura quies (173.) — kevesen élnek így, helyette örökösen ambícióikat kergetik a nagyvárosok nyugtalan tömegében. Kívánság megfogalmazá-

${ }^{27}$ Legutoljára: S. E. Lawrence: The God That is Truly God and the Universe of Euripides' Heracles. Mnemosyne 51/2. (1998). 129-146.

${ }_{28}$ Érdekesek és ebból a szempontból tanulságosak Fitch (i. m. 1987. 35-40) elemzései, melyekben rámutat, milyen kevéssé változtatja meg $\mathrm{H}$. alapvető jellemét az átélt tragédia. Felkiáltásai ugyanolyan megalomániásak, és még mindig csak az erőszakot látja egyetlen eszközének, amellyel helyzetét megoldhatja.

${ }^{29}$ Sokan úgy vélik, a Seneca-tragédiákban megszokott módon itt is a józan kívülálló véleményét szólaltatja meg a kar, azaz a szerző által követett és helyeselt értékrend tükröződik a kardalban. Természetesen ezt a nézetet elsôsorban azok a tudósok vallják, akik a tragédia Herculesében nem tudnak idealizált hőst látni. Ennek a véleménynek a legteljesebb kifejtése: $P$. Grisoli: Per interpretazione del primo canto corale dell' H. F. di Seneca. Boll.Class. 19 (1971) 73-99. illetve O. Zwierlein: Kritischer Kommentar zu den Tragödien Senecas. Stuttgart 1986. 33-38. Mások, a „pozitív olvasat” követói éppen ellenkezóleg, a secura quies és a virtus animosa ellentétében a sztoicizmus és az epikureizmus vitáját látják tükröződni, és egyértelmúnek vélik, hogy Seneca szavazatát csakis az utóbbi mellett teheti le, tehát a korus egyszerúen a hősiességre képtelen kisember álláspontját fogalmazza meg, hogy ezáltal még fényesebb legyen az altruista főhős virtusának ragyogása. Ez utóbbi táborhoz tartozik az a szerző is, akitôl a kardal eddigi legrészletesebb vizsgálata származik, G. Mader (i. m.) is. 
sával fejezi be elmélkedését a kórus: me mea tellus| lare secreto tutoque tegat (196. sk.).

A carmen ellenpontot képez a fötörténettel, Hercules tragédiáját a secura quies és a virtus animosa ellentétében definiálja, arra világít rá, hogy Hercules tragédiája az elégedettségre képtelen, mindig feljebb, mindig többre igyekvő emberi akarat tragédiája. A gondolatmenet az egyre magasabbra törekvés tragikusan törvényszerú összeomlását mutatja meg, a bukás okait pedig az emberi psziché immanens törvényszerúségeiben találja meg. Az emberi emelkedési, bizonyítási vágynak szolgálatában állhat a fizikai erô vagy az intellektuális képesség, legyőzhetnek minden előttük álló akadályt, de spirituális adottságait nem változtathatja meg. A határtalan emelkedést nem volt képes követni Hercules belső harmóniája. Érdekesen fordítja a visszájára a mítoszt a novit paucos secura quies kijelentés: a tömeges köznapiság és kiválasztott egyediség vonatkozásában a mitológiai hagyománnyal éppen ellentétesen látja a fószereplót: a mítosz világában Hercules a kivételes, egyedi és páratlan az emberek világában, Seneca számára azonban az a kivételes, ha valaki képes a secura quies követésére, és ebben a tekintetben Hercules átlagember, nem tartozik a pauci közé, kivételessége csak ambícióinak mértékében, illetve a megvalósítás intenzitásában mutatkozik meg. Ezzel Seneca tragédiája abba a hosszú európai irodalmi tradícióba illeszkedik, amelyik az akarat, illetve önnön korlátainknak átlépésére irányuló veleszületett, nagyon is emberi kívánságának a tragikumát járja körül. Ez a vágy az, amelyet pl. Goethe Mantója úgy fogalmaz meg: den lieb’ ich, der Unmögliches begehrt. Faust, a tudás atlétája ugyanabba a korlátba ütközik, mint az ókori tragédia erőbajnoka, saját emberlétének belsô határaiba. 